\title{
Parasite loAd IN GUINeA PIg foetus With ReAL time PCR AFTER MATERNOFOETAL TRANSMISSION OF TOXOPLASMA GONDII
}

\author{
FLORI P.*, HAFID J.**, THONIER V.*, BELLETE B.* RABERIN H.* \& TRAN MANH SUNG R.*
}

\section{Summary:}

Parasite loads of different tissues were assessed in guinea pig foetus after maternal infection. Twelve female guinea pigs were infected with 100 cysts of the $76 \mathrm{~K}$ strain of Toxoplasma gondii by the oral route. Inoculation was performed $20 \pm 5$ days (G2O) or $40 \pm 5$ days $(\mathrm{G} 40)$ after the beginning of gestation.

Gestational age was determined by progesterone assay. Maternal and foetal organ samples were taken 60 days after the beginning of gestation. Parasite loads (from placenta, amniotic fluid (AF), cord blood (CB), foetal brain, liver, lung and spleen) were assessed by a real-time PCR quantification using fluorescence resonance energy transfer (FRET) hybridization probes on the light Cycler $^{\circledR}$. Congenital transmission was proven by the presence of parasites in blood or tissue samples of the foetus in $84.6 \%$ $(11 / 13)$ and $100 \%(16 / 16)$ of cases after inoculation on G20 and $G 40$, respectively. The quantitative analysis of our results after inoculation at $G 20$ and $G 40$ has allowed us to determinate the positive parasitic loads as a function of the origin of the sample and the period of inoculation. The parasite loads expressed as log (parasite/g) were low in AF and CB samples: $1.49 \pm 0.50$ and $1.05 \pm 0.10$ at $G 20$ and $1.21 \pm 0.36$ and $1.20 \pm 0.42$ at $\mathrm{G} 40$ respectively. In contrast the placenta and the different foetal tissues had higher parasite burdens: $2.89 \pm 0.54$ to $5.30 \pm$ 0.51 at $\mathrm{G} 20$ and $2.81 \pm 0.71$ to $3.65 \pm 0.59$ at $\mathrm{G} 40$. All the placentae were positive for parasites even in the two cases with no proven transmission. Real time quantitative PCR using the hybridization probe was a very sensitive and reproducible technique to study the kinetics of congenital toxoplasmosis in the guinea pig model wich is close to that of humans.

KEY WORDS : congenital toxoplasmosis, parasite load, guinea-pig, real-time PCR.
Résumé : Détermination PaR PCR QUantTTATIVE EN TEMPS RÉEl DE LA CHARGE TOXOPLASMIQUE DE TISSUS DE FEETUS DE COBAYES APRÈS INFESTATION MATERNELLE

Les charges toxoplasmiques de différents tissus de foetus de cobaye ont été déterminées après infestation maternelle. Douze cobayes gestantes ont été infestées avec 100 kystes de la souche $76 \mathrm{~K}$ par voie orale. Cette infestation a eu lieu après le début de la gestation soit à 20 jours ( \pm 5) (G20), soit à 40 jours ( \pm 5) (G40) de gestation. Le prélèvement des organes foetaux a été effectué à 60 jours de gestation (G60) soit cinq jours avant terme. Les charges parasitaires (Placenta, liquide amniotique (LA), sang de cordon (SC), foie, cerveau, poumon, et ratel ont été déterminées par PCR quantitative en temps réel (technique Sonde-sonde) sur Light-Cycler ${ }^{\circledR}$ L'analyse qualitative de nos résultats nous a permis d'affirmer une transmission maternofoetale (organes foetaux et/ou sang de cordon positif) chez 84,6\% (1 1/13) foetus après infestation maternelle à G20 et chez $100 \%(16 / 16)$ après infestation à G40. L'analyse quantitative après infestation à $G 20$ et à $G 40$ nous a permis de déterminer les charges parasitaires en fonction de la période d'infestation et de l'origine du prélèvement. Ces charges parasitaires exprimées en log (parasites/g) sont relativement faibles pour les LA et les SC : 1,49 $\pm 0,50$ et 1,05 $\pm 0,1$ à $G 20$ et 1,21 $\pm 0,36$ et 1,20 $\pm 0,42$ à G40. À l'inverse, les charges placentaires et des différents organes foetaux sont bien plus importantes : de 2,89 \pm 0,54 à $5,30 \pm 0,51$ à $G 20$ et de 2,81 $\pm 0,71$ à 3,65 $\pm 0,59$ à G40. Les charges placentaires sont systématiquement positives même pour les deux cas où la transmission congénitale n'a pas été prouvée. Dans cette étude nous avons pu apprécier les avantages de la PCR quantitative en temps réel pour déterminer l'atteinte tissulaire foetale après transmission congénitale à partir d'un modèle cobaye, modèle présentant certaines similititudes avec la pathologie humaine.

MOTS CLÉS : toxoplamose congénitale, charge parasitaire, cobaye, PCR en temps réel.

nocompetent humans, toxoplasmosis may cause severe disorders in immunocompromised individuals and in pregnant women because of the high risk of transplacental transmission and the occurrence of abortion or multiple congenital lesions in the foetus (Desmonts \& Couvreur, 1974; Foulon et al., 1999a). In the diagnosis of congenital infection in humans, the search for parasite is mainly carried out by the PCR technique and as a second line by mouse inoculation. Using molecular techniques, diagnosis is made by the detection of specific DNA in amniotic fluid (Hohlfeld et al., 1993; Pralong et al., 1994; Hezard et al., 1997; Gratzl et al., 1998; Robert-Gangneux et al.,. 1999; Foulon et al., 1999b; Romand et al., 2001; Bessieres et al., 2001),

\footnotetext{
* Groupe Immunité des Muqueuses et Agents Pathogènes (GIMAP), Faculté de Médecine Jacques Lisfranc, 15, rue Ambroise Paré, 42023 Saint-Étienne, France.

** Unité d'Immunologie et de Physiologie, Département de biologie Faculté des Sciences et Techniques, Avenue A. El Khattabi, BP 618 40000 Marrakech, Morocco.

Correspondence: Dr Pierre Flori, Laboratoire de Parasitologie, CHU de Saint-Étienne, Hôpital Nord, 42055 Saint-Étienne cedex 2, France Tel.: 33 (0) 477828308 - Fax: 33 (0) 477828482 .

E-mail: pierre.flori@univ-st-etienne.fr
} 
or more rarely in placenta (Fricker-Hidalgo et al., 1998). More recently, the quantification of specific DNA, has been possible by different techniques of quantitative PCR (Costa et al., 2000; Lin et al., 2000; Costa et al., 2001; Kupferschmidt et al., 2001).

In animals, several studies have described the kinetics of different tissue loads from adult animals (rats, mice or pigs), either by semi-quantitative cell culture (Piketty et al., 1990; Derouin \& Garin, 1991; Zenner et al., 1998), or more recently by semi-quantitative or quantitative PCR (Luo et al., 1997; Jaureguy et al., 2001). Moreover, other studies have described the congenital transmission in differents animals, such as mice (Beverley, 1959; Remington et al., 1961; Roberts \& Alexander, 1992), rats (Dubey \& Shen, 1991; Zenner et al., 1993; Dubey et al., 1997; Paulino \& Victor, 1999; Freyre et al., 1999), guinea pigs (Giraud et al., 1965; Bérard-Badier et al., 1968; Wright, 1972, Haumont et al., 2000; Flori et al., 2002), pigs (Dubey \& Urban, 1990), and even in rhesus monkeys (Schoondermarkvan de Ven et al., 1993; 1997 ). However, only our previous study (Flori et al., 2002) has given some information about the quantitative load in tissues (brain and liver) of guinea pig newborns.

No studies have described the quantitative load from placentae, amniotic fluid or tissues of foetuses. Thus, the objective of the present study was to describe the parasite load in these tissues which was assessed by real-time quantitative PCR using fluorescence resonance energy transfer (FRET) hybridization probes on the Light-Cycler ${ }^{\circledR}$ instrument. For this we have used the guinea pig model of congenital toxoplasmosis which allows for sufficient time to obtain high parasite levels in the tissues due to its long gestational period of 65 days. The other advantage of choosing this model was that the $76 \mathrm{~K}$ strain (Type II) of Toxoplasma gondii induces a high rate (86\%) of maternofoetal transmission (Flori et al., 2002).

\section{MATERIALS AND METHODS}

\section{ANIMALS AND PARASITES}

F Temale and male Dunkin Hartley guinea pigs were purchased from Harlan (Gannat, France). 1 Twelve females weighing 600-800 g were transferred to our animal facilities. Their sera were obtained by intracardiac puncture and the absence of Toxoplasma antibodies was checked by indirect immunofluorescence antibody test (IFAT).

The Toxoplasma gondii $76 \mathrm{~K}$ strain of Type II (Ajzenberg et al., 2002a) was used. Type II isolates were largery predominant in human congenital toxoplasmosis (Ajzenberg et al., 2002b). As described previously (Godard et al., 1990), this strain was maintained by oral inoculation of cysts in OF1 mice (Charles RIVER, L'Arbresle, France) every three months. The cysts obtained from the brains of OF1 mice which were infected three months earlier, were used for oral infection. Under sterile conditions, these brains were homogenized in $20 \mathrm{ml}$ Potter's tubes, and the cysts were counted and diluted as necessary (five to 20 factor dilution).

The Toxoplasma gondii RH strain (Type I, Ajzenberg et al., 2002a) was maintained through successive intraperitoneal tachyzoite passages in mouse every three days as described previously (Hafid et al., 1989). The tachyzoites obtained from peritoneal fluid of OF1 mice (Charles RIVER, L'Arbresle, France) infected three days earlier were used to obtain a range of standards for real time quantitative PCR assays after counting with Nageotte cells.

\section{MATING AND INFECTION OF FEMALE GUINEA PIGS}

For mating, four groups of three female guinea pigs were kept in separate cages with one male. After 18 days (duration of the menstrual cycle), the female guinea pigs were housed in individual cages and grouped according to the time of inoculation. On day 20 and 27 after the beginning of mating, two serum progesterone (Pg) measurements (Access ${ }^{\circledR}$ BeckmanCoulter, Villepinte, France) were performed to confirm and date the gestational age (Thapar et al., 1988). If the first sample was superior to $20 \mu \mathrm{g} / \mathrm{l}$ (Pg), it was assessed that the female became pregnant in the first part of mating (between days 0 to 10) ; if the second sample only was superior to $20 \mu \mathrm{g} / \mathrm{l}$ (Pg), it was assessed that the female became pregnant in the second part of mating (between days 8 to 18 ).

All guinea pigs were infected by oral route (OR) with 100 cysts from the $76 \mathrm{~K}$ strain. Animals were infected as follows: six guinea pigs on day 20 (G20 \pm 5 days), and six guinea pigs on day 40 ( G40 \pm 5 days) after the beginning of gestation. To confirm the infestation, T. gondii IFAT was performed on day 14 and on day 30 after inoculation.

\section{FOETAL ORGAN HARVESTING}

The full gestational period is $65 \pm 5$ days. Euthanesia of gestational guinea pigs using phenobarbital was performed on the $60^{\text {th }}$ day (G60) after the beginning of gestation. For each dead animal, a laparotomy was carried out. Then the uterus was opened, each amniotic fluid (AF) punctured and each individual chorion separated. The chorion was then opened and the cord was punctured after washing with distilled water in order to avoid possible contamination with circulating parasites from maternal blood or from AF. Each foetus was weighed and thoroughly washed. At last, each placenta, brain, liver, lung and spleen were removed 
separately with sterile instruments, washed in PBS, wiped and weighed. Parts of these organs were then placed in $1.5 \mathrm{ml}$ Eppendorf tubes. Homogenization and grinding was performed using a pestle for Eppendorf.

\section{ReAl TIME QUantitative PCR}

\section{- Extraction and purification}

To detect $T$. gondii DNA in cord blood and amniotic fluid, $200 \mu \mathrm{l}$ of each was used for DNA extraction. To detect $T$. gondii DNA in the organ homogenates, $50 \mu \mathrm{g}$ of tissue were used for DNA extraction with the High Pure PCR Template Preparation Kit ${ }^{\circledR}$ (Roche Molecular Biochemicals, Meylan, France) according to the manufacturer's recommandations. The final concentration of DNA was determined between 100 and $500 \mathrm{mg} / \mathrm{l}$ depending on the tissue $(100-200 \mathrm{mg} / 1$ for the brain extracts and $150-300 \mathrm{mg} / \mathrm{l}$ for liver extracts, $200-400 \mathrm{mg} / \mathrm{l}$ for placenta and spleen extracts and 300-500 mg/l for lung extracts). The purity of DNA was measured by UV spectrophotometry (OD $260 \mathrm{~nm} / \mathrm{OD} 280 \mathrm{~nm}$ between 1.6 and 1.8).

- Real-Time Quantitative PCR on Light Cycler ${ }^{\circledR}$ The real time quantitative PCR was performed by fluorescence resonance energy transfer (FRET) hybridization probes on the Light Cycler ${ }^{\circledR}$. PCR was performed with "LC FastStart DNA Master hybridization Probes ${ }^{\circledR}$ (Roche Molecular Biochemicals, Meylan, France)" in a standard PCR reaction as previously described (Costa et al., 2000). Briefly, $20 \mu \mathrm{l}$ of mixture containing Fast Start Taq DNA polymerase, dNTP (with dUTP instead of dTTP), $0.5 \mu \mathrm{M}$ of each selected primer, $0.25 \mu \mathrm{M}$ of each hybridization probes derived from the $T$. gondii B1 gene, $3 \mathrm{mM} \mathrm{MgCl}_{2}$ and exactly $500 \mathrm{ng}$ of tissue DNA in $5 \mu \mathrm{l}$ of the extracts. To prevent potential carry-over contamination of the amplified target DNA from previous reactions, the $\mathrm{PCR}$ reaction mix was initially incubated with heat-labile Uracyl-DNA-glycosilase (Roche Molecular Biochemicals, Meylan, France) for five min at room temperature. Amplification, detection and quantification were carried out using the LightCycler $^{\circledR}$ instrument (Roche Molecular Biochemicals, Meylan, France) as previously described.

To obtain the standards for the real time quantitative PCR assays, the trophozoites of an RH strain obtained from an infected mouse peritoneal fluid (see "animals and parasites") were quantified with Nageotte cells. Then the DNA was extracted under the same conditions as the test tissues and a series of 10-fold dilutions ( $10^{1}-10^{6}$ parasites/extract) were made. To simulate the contents of the test tissue extracts, $500 \mathrm{ng}$ of DNA extract from tissues of an uninfected guinea pig were added into each dilution. This range of dilutions was then included in each amplification run to give the standard curve. Using these standards, we have determined the parasitic load expressed as the number of parasites $/ \mathrm{ml}$ of body fluid or parasites $/ \mathrm{g}$ of tissue.

\section{STATISTICAL ANALYSIS}

To evaluate the reproducibility of the probe hybridization technique, standard deviations (SD) of all the quantitative results for the 108 standards were analysed. Statistical assessment of differences in mean of $\log$ parasite load was done by unpaired Student's t-test ( $\mathrm{p}<$ 0.05 was considered significant). Spearman's rank correlation test was done to determine the association between parasite load and time elapsed between infection and foetal organ harvesting.

\section{RESULTS}

ll guinea pigs except guinea pig $G$ (which died
prematurely at G52) were diagnosed as having
been infected before sacrifice (seroconversion by the IFAT). Guinea pig $\mathrm{G}$ died before blood samples were taken but its status was confirmed by maternal tissues (liver and lung) burdens and by a positive placenta.

Only 10 of the 12 guinea pigs could be included in our protocol; the other two aborted early on days 30 and 32 after the beginning of gestation (10 and 12 days after inoculation on G20) (Table I) and offspring could not be counted because of maternal cannibalism. Of the 10 guinea pigs, one died on day 52 after the beginning of gestation (12 days after inoculation on G40): after laparotomy, three fetuses were recovered (guinea pig G). Another one (guinea pig B) aborted two fetuses on G55 (15 days after inoculation on G40) (Table II). For the remaining female guinea pigs, euthanasia was performed on the $60^{\text {th }}$ day (G60) after the beginning of gestation as previously described and 24 fetuses were recovered. In all, 29 fetuses were recovered. Twenty seven of these were apparently normal with variable weights between 40 to $110 \mathrm{~g}$ depending on their gestational age ( $G 52$ to $G 60 \pm 5$ days). The two remaining fetuses died in utero, their weights were 4 and $12 \mathrm{~g}$, respectively (Table $\mathrm{I}$ ).

\section{EVALUATION OF THE REPRODUCIBILITY OF THE PROBES HYBRIDIZATION QUANTIFICATION TECHNIQUE}

3/12 standards with one parasite/extract, 5/12 standards with two parasites/extract and all standards above 10 parasites/extract were positive. The standard deviation (SD) of the mean for 10 parasites/extract was \pm 7.27 and for standards above 100 parasites/extract, the quantification was found to be more accurate (Table III). 
Parasite load

\begin{tabular}{|c|c|c|c|c|c|c|c|c|c|c|}
\hline \multirow[b]{2}{*}{$\begin{array}{l}\text { Female } \\
\text { guinea pig }\end{array}$} & \multirow[b]{2}{*}{$\begin{array}{l}\text { Number } \\
\text { of foetuses }\end{array}$} & \multirow[b]{2}{*}{$\begin{array}{c}\text { Day of } \\
\text { organ sample }\end{array}$} & \multirow[b]{2}{*}{$\begin{array}{l}\text { Weight } \\
\text { of foetus } \\
\text { (g) }\end{array}$} & \\
\hline & & & & $\begin{array}{c}\text { Amniotic } \\
\text { fluid } \\
\text { (parasite/ml) }\end{array}$ & $\begin{array}{c}\text { Placenta } \\
\text { (parasite/g) }\end{array}$ & $\begin{array}{c}\text { Foetal } \\
\text { blood } \\
\text { (parasite } / \mathrm{ml} \text { ) }\end{array}$ & $\begin{array}{c}\text { Liver } \\
\text { (parasite/g) }\end{array}$ & $\begin{array}{c}\text { Brain } \\
\text { (parasite } / g \text { ) }\end{array}$ & $\underset{\text { (parasite/g) }}{\text { Lung }}$ & $\begin{array}{c}\text { Spleen } \\
\text { (parasite/g) }\end{array}$ \\
\hline $\mathbf{E}$ (abortion on day 32) & $?$ & No sample & & & & & & & & \\
\hline $\mathbf{J}$ (abortion on day 30 ) & $?$ & No sample & & & & & & & & \\
\hline $\mathbf{L}$ & $\begin{array}{l}1 \text { (necrosis foetus) } \\
2 \text { (necrosis foetus) } \\
3\end{array}$ & G60 & $\begin{array}{r}\mathbf{4} \\
\mathbf{1 2} \\
95\end{array}$ & $\begin{array}{c}\mathrm{NP} \\
\mathrm{NP} \\
9,5.10^{1}\end{array}$ & $\begin{array}{l}3,20.10^{4} \\
8,00.10^{5} \\
4,06 \cdot 10^{5}\end{array}$ & $\begin{array}{c}\mathrm{NP} \\
\mathrm{NP} \\
\text { negative }\end{array}$ & $\begin{array}{c}\text { Thoracic biopsy } \\
\text { Thoracic biopsy } \\
1,44.10^{4}\end{array}$ & $\begin{array}{l}\text { y only: } 3,22 \cdot 10^{3} \\
\text { y only: } 2,08 \cdot 10^{3} \\
2,33 \cdot 10^{5}\end{array}$ & $2,41 \cdot 10^{4}$ & $6,60 \cdot 10^{2}$ \\
\hline $\mathbf{A}$ & $\begin{array}{l}\mathbf{1} \\
\mathbf{2} \\
\mathbf{3}\end{array}$ & G60 & $\begin{array}{l}75 \\
75 \\
80\end{array}$ & $\begin{array}{l}1,0.10^{1} \\
7,5.10^{1} \\
1,0.10^{1}\end{array}$ & $\begin{array}{l}2,02 \cdot 10^{5} \\
3,36 \cdot 10^{5} \\
4,12 \cdot 10^{5}\end{array}$ & $\begin{array}{l}\text { negative } \\
\text { negative } \\
\text { negative }\end{array}$ & $\begin{array}{l}1,26.10^{3} \\
1,58.10^{4} \\
3,20.10^{2}\end{array}$ & $\begin{array}{l}2,99 \cdot 10^{5} \\
6,61 \cdot 10^{4} \\
3,00.10^{3}\end{array}$ & $\begin{array}{l}3,60 \cdot 10^{4} \\
3,56 \cdot 10^{4} \\
6,40 \cdot 10^{3}\end{array}$ & $\begin{array}{l}2,12 \cdot 10^{3} \\
4,20 \cdot 10^{3} \\
6,20 \cdot 10^{2}\end{array}$ \\
\hline $\mathbf{H}$ & $\begin{array}{l}1 \\
2 \\
3\end{array}$ & G60 & $\begin{array}{l}80 \\
80 \\
90\end{array}$ & $\begin{array}{r}2,0.10^{1} \\
5.10^{0} \\
4,0.10^{1}\end{array}$ & $\begin{array}{l}1,5 \cdot 10^{6} \\
1,02 \cdot 10^{5} \\
1,30 \cdot 10^{5}\end{array}$ & $\begin{array}{c}1,0.10^{1} \\
\text { negative } \\
1,0.10^{1}\end{array}$ & $\begin{array}{l}\text { negative } \\
1,72 \cdot 10^{3} \\
1,60 \cdot 10^{3}\end{array}$ & $\begin{array}{l}7,20.10^{3} \\
\text { negative } \\
\text { negative }\end{array}$ & $\begin{array}{l}1,06 \cdot 10^{4} \\
6,40 \cdot 10^{3} \\
2,37.10^{4}\end{array}$ & $\begin{array}{l}1,20.10^{2} \\
1,60.10^{2} \\
\text { negative }\end{array}$ \\
\hline $\mathbf{I}$ & $\begin{array}{l}1 \\
2 \\
3 \\
4\end{array}$ & G60 & $\begin{array}{l}65 \\
70 \\
70 \\
70\end{array}$ & $\begin{array}{l}\text { negative } \\
1,25 \cdot 10^{2} \\
7,5 \cdot 10^{1} \\
\text { negative }\end{array}$ & $\begin{array}{l}2,40 \cdot 10^{5} \\
3,20 \cdot 10^{4} \\
3,80 \cdot 10^{5} \\
4,86 \cdot 10^{4}\end{array}$ & $\begin{array}{c}\text { negative } \\
1,5.10^{1} \\
\text { negative } \\
\text { negative }\end{array}$ & $\begin{array}{l}\text { negative } \\
3,14.10^{3} \\
2,02.10^{3} \\
\text { negative }\end{array}$ & $\begin{array}{l}\text { negative } \\
6,07.10^{5} \\
1,54.10^{5} \\
\text { negative }\end{array}$ & $\begin{array}{l}\text { negative } \\
3,02 \cdot 10^{4} \\
3,98 \cdot 10^{3} \\
\text { negative }\end{array}$ & $\begin{array}{l}\text { negative } \\
2,20.10^{3} \\
8,00.10^{2} \\
\text { negative }\end{array}$ \\
\hline
\end{tabular}

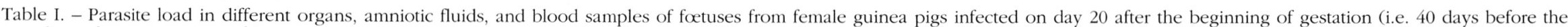
sampling of tissue on day G60).

\begin{tabular}{|c|c|c|c|c|c|c|c|c|c|c|}
\hline \multirow[b]{2}{*}{$\begin{array}{l}\text { Female } \\
\text { guinea pig }\end{array}$} & \multirow[b]{2}{*}{$\begin{array}{l}\text { Number } \\
\text { of foetuses }\end{array}$} & \multirow[b]{2}{*}{$\begin{array}{c}\text { Day of } \\
\text { organ sample }\end{array}$} & \multirow[b]{2}{*}{$\begin{array}{l}\text { Weight } \\
\text { of foetus } \\
\text { (g) }\end{array}$} & \multicolumn{7}{|c|}{ Parasite load } \\
\hline & & & & $\begin{array}{c}\text { Amniotic } \\
\text { fluid } \\
\text { (parasite/ml) }\end{array}$ & $\begin{array}{c}\text { Placenta } \\
\text { (parasite/g) }\end{array}$ & $\begin{array}{c}\text { Foetal } \\
\text { blood } \\
\text { (parasite/ml) }\end{array}$ & $\begin{array}{c}\text { Liver } \\
\text { (parasite/g) }\end{array}$ & $\begin{array}{c}\text { Brain } \\
\text { (parasite/g) }\end{array}$ & $\underset{\text { (parasite/g) }}{\text { Lung }}$ & $\begin{array}{c}\text { Spleen } \\
\text { (parasite/g) }\end{array}$ \\
\hline $\begin{array}{l}\text { G (maternal death } \\
\text { on day } 52 \text { ) }\end{array}$ & $\begin{array}{l}1 \\
2 \\
3\end{array}$ & G52 & $\begin{array}{l}40 \\
45 \\
40\end{array}$ & $\begin{array}{l}\text { NP } \\
\text { NP } \\
\text { NP }\end{array}$ & $\begin{array}{l}5,60 \cdot 10^{2} \\
7,00 \cdot 10^{2} \\
6,80 \cdot 10^{2}\end{array}$ & $\begin{array}{l}\text { NP } \\
\text { NP } \\
\text { NP }\end{array}$ & $\begin{array}{l}\text { negative } \\
\text { negative } \\
\text { negative }\end{array}$ & $\begin{array}{l}\text { negative } \\
\text { negative } \\
\text { negative }\end{array}$ & $\begin{array}{l}2,80.10^{2} \\
2,00.10^{2} \\
2,40.10^{2}\end{array}$ & $\begin{array}{l}\text { negative } \\
\text { negative } \\
\text { negative }\end{array}$ \\
\hline B (abortion on day 55) & $\begin{array}{l}1 \\
2\end{array}$ & G55 & $\begin{array}{l}60 \\
65\end{array}$ & $\begin{array}{l}\text { NP } \\
\text { NP }\end{array}$ & $\begin{array}{l}\text { NP } \\
\text { NP }\end{array}$ & $\begin{array}{l}\text { NP } \\
\text { NP }\end{array}$ & $\begin{array}{l}3,60 \cdot 10^{2} \\
6,40.10^{2}\end{array}$ & $\begin{array}{l}\text { negative } \\
\text { negative }\end{array}$ & $\begin{array}{l}7,10.10^{3} \\
9,30 \cdot 10^{3}\end{array}$ & $\begin{array}{l}1,20.10^{2} \\
1,00.10^{3}\end{array}$ \\
\hline C & $\begin{array}{l}1 \\
2\end{array}$ & G60 & $\begin{array}{l}85 \\
90 \\
\end{array}$ & $\begin{array}{c}\text { negative } \\
2,8.10^{1} \\
\end{array}$ & $\begin{array}{l}4,20 \cdot 10^{3} \\
4,00 \cdot 10^{4} \\
\end{array}$ & $\begin{array}{l}\text { negative } \\
\text { negative }\end{array}$ & $\begin{array}{l}3,60 \cdot 10^{3} \\
1,60.10^{3}\end{array}$ & $\begin{array}{l}\text { negative } \\
4,00 \cdot 10^{1}\end{array}$ & $\begin{array}{l}2,80.10^{3} \\
2,40.10^{3}\end{array}$ & $\begin{array}{l}\text { negative } \\
6,00.10^{2}\end{array}$ \\
\hline D & $\begin{array}{l}1 \\
2\end{array}$ & G60 & $\begin{array}{l}105 \\
110\end{array}$ & $\begin{array}{r}5.10^{0} \\
1,0.10^{1}\end{array}$ & $\begin{array}{l}1,50 \cdot 10^{4} \\
1,84 \cdot 10^{4}\end{array}$ & $\begin{array}{c}1,0.10^{1} \\
\text { negative }\end{array}$ & $\begin{array}{l}1,86 \cdot 10^{3} \\
3,60 \cdot 10^{2}\end{array}$ & $\begin{array}{l}4,60.10^{2} \\
1,50.10^{3}\end{array}$ & $\begin{array}{l}4,06.10^{3} \\
3,76.10^{3} \\
\end{array}$ & $\begin{array}{l}\text { negative } \\
\text { negative }\end{array}$ \\
\hline $\mathbf{F}$ & $\begin{array}{l}1 \\
2 \\
3\end{array}$ & G60 & $\begin{array}{l}70 \\
75 \\
75\end{array}$ & $\begin{array}{c}\text { negative } \\
1,5.10^{1} \\
1,0.10^{1}\end{array}$ & $\begin{array}{l}1,36.10^{4} \\
3,60.10^{3} \\
1,02.10^{4}\end{array}$ & $\begin{array}{c}\text { negative } \\
\text { negative } \\
3,2.10^{1}\end{array}$ & $\begin{array}{l}2,48.10^{3} \\
4,40.10^{2} \\
\text { negative }\end{array}$ & $\begin{array}{l}\text { negative } \\
\text { negative } \\
\text { negative }\end{array}$ & $\begin{array}{l}8,40.10^{2} \\
1,00.10^{4} \\
\text { negative }\end{array}$ & $\begin{array}{l}1,00.10^{3} \\
1,20.10^{3} \\
\text { negative }\end{array}$ \\
\hline $\mathbf{K}$ & $\begin{array}{l}1 \\
2 \\
3 \\
4\end{array}$ & G60 & $\begin{array}{l}70 \\
80 \\
85 \\
85\end{array}$ & $\begin{array}{l}1,5 \cdot 10^{1} \\
1,0.10^{1} \\
8,5 \cdot 10^{1} \\
3,0.10^{1}\end{array}$ & $\begin{array}{l}8,00 \cdot 10^{3} \\
4,20 \cdot 10^{3} \\
1,10 \cdot 10^{3} \\
6,30 \cdot 10^{3}\end{array}$ & $\begin{array}{c}\text { negative } \\
\text { negative } \\
5.10^{0} \\
3,9.10^{1}\end{array}$ & $\begin{array}{l}2,16 \cdot 10^{3} \\
4,20.10^{2} \\
3,90.10^{3} \\
2,52.10^{3}\end{array}$ & $\begin{array}{c}1,48.10^{3} \\
3,80.10^{2} \\
4,40.10^{3} \\
\text { negative }\end{array}$ & $\begin{array}{l}6,24 \cdot 10^{3} \\
1,58 \cdot 10^{3} \\
1,48 \cdot 10^{4} \\
1,51 \cdot 10^{4}\end{array}$ & $\begin{array}{c}7,80 \cdot 10^{2} \\
2,20 \cdot 10^{2} \\
3,14.10^{3} \\
\text { negative }\end{array}$ \\
\hline
\end{tabular}

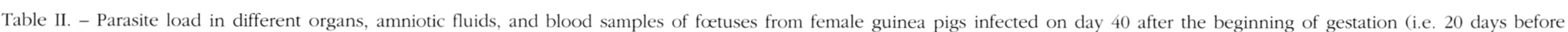
the sampling of tissue on day G60). 


\begin{tabular}{ccccc}
\hline $\begin{array}{c}\text { Standards } \\
\text { (parasites/extract) }\end{array}$ & $\begin{array}{c}\mathbf{N} \\
\text { (number } \\
\text { of standards) }\end{array}$ & $\begin{array}{c}\text { No } \\
\text { of positive } \\
\text { No reactions (\%) }\end{array}$ & $\begin{array}{c}\text { Mean Crossing point } \\
\text { ( } \pm \text { SD) (cycle No) }\end{array}$ & $\begin{array}{c}\text { Mean calculated } \\
\text { concentration }( \pm \text { SD) } \\
\text { (parasites/extract) }\end{array}$ \\
\hline 1 & 12 & $3(25)$ & $39.00( \pm$ ND) & $3.1( \pm$ ND) \\
2 & 12 & $5(42)$ & $38.84( \pm 0.71)$ & $4.1( \pm 3.3)$ \\
10 & 14 & $14(100)$ & $37.58( \pm 1.01)$ & $13.5( \pm 7.27)$ \\
100 & 14 & $14(100)$ & $34.10( \pm 0.75)$ & $92( \pm 27)$ \\
10,00 & 14 & $14(100)$ & $30.49( \pm 0.49)$ & $940( \pm 240)$ \\
100,000 & 14 & $14(100)$ & $27.14( \pm 0.31)$ & $9,710( \pm 1,490)$ \\
$1,000,000$ & 14 & $14(100)$ & $23.44( \pm 0.26)$ & $100,100( \pm 8,100)$ \\
\hline
\end{tabular}

(ND: not determined; SD: standard deviation).

Table III. - Quantitative results of all 108 standards analysed.

\section{MATERNOFOETAL TRANSMISSION OF TOXOPLASMOSIS}

An offspring was deemed infected when at least one organ (brain, liver, lung or spleen) or when cord blood was positive. It was observed that $84.6 \%(11 / 13)$ were infected after inoculation at G20 and $100 \%$ $(16 / 16)$ at $\mathrm{G} 40$.

When assessing maternofoetal transmission of toxoplasmosis based on the origin of the samples (body fluid or tissue), the positivity raters were as follows: $35 \%(7 / 20)$ of cord blood (CB), $90 \%(18 / 20)$ of amniotic fluids (AF), $100 \%(29 / 29)$ of placentae and $52 \%(13 / 25), 64 \%(16 / 25), 80 \%(20 / 25)$ and $96 \%$ $(24 / 25)$ of brain, spleen, liver and lung tissues respectively (Tables I and II). All the placentae were positive for parasites including the two cases with no proven transmission.

\section{PARASITIC LOAD ACCORDING TO TYPE OF TISSUE AND TIME OF INOCULATION}

The quantitative analysis of our results after inoculation at G20 and G40 has allowed us to determinate the parasitic loads as a function of the origin of the sample and the period of inoculation. The positive parasitic loads expressed as log (parasite/g) at G20 and G40 after inoculation were respectively: $1.05 \pm 0.1$ $(\mathrm{n}=3)$ and $1.20 \pm 0.42(\mathrm{n}=4)$ for CB; $1.49 \pm 0.50$ $(\mathrm{n}=9)$ and $1.21 \pm 0.36(\mathrm{n}=9)$ for AF; $4.85 \pm 0.86$ $(\mathrm{n}=7)$ and $2.81 \pm 0.71(\mathrm{n}=6)$ for foetal brains; $2.89 \pm$ $0.54(\mathrm{n}=11)$ and $2.83 \pm 0.44(\mathrm{n}=8)$ for foetal spleens; $3.40 \pm 0.56(n=8)$ and $3.08 \pm 0.41(n=12)$ for foetal livers; $4.18 \pm 0.37(n=9)$ and $3.42 \pm 0.60(n=15)$ for foetal lungs and $5.30 \pm 0.51(n=13)$ and $3.65 \pm 0.59$ $(n=14)$ for placentae. Parasitic loads of amniotic fluid and cord blood were low [0.70 to $2.10 \log$ (parasites/g)] whereas it was high in foetal organs or placenta $[2.08$ to $6.18 \log$ (parasites/g)] (Student's t-test, $\mathrm{p}<0.001$ ). Moreover, the parasite load in placenta was higher than that in foetal organs (Fig. 1).

The parasite load of placenta and brain was timedependent. Thus, parasite load from placenta was bet- ween 2.75 to $2.85 \log$ (parasite/g) 12 days after inoculation (guinea pig G), between 3.04 to $4.60 \mathrm{log}$ (parasite/g) 15-20 days after inoculation (group G40: guinea pig C, D, F, K) and between 4.51 to $6.18 \log$ (parasite/g) 40 days after inoculation (Group G20: guinea pig A, H, I, L). The correlation coefficient between the log of placenta parasite load and the delay post-infection was 0.89 (Spearman's rank correlation test, $\mathrm{p}<0.01$ ). The difference in parasitic load between day 20 and day 40 post infection was statistically significant (Student's t-test, $\mathrm{p}<0.001$ ). A similar increase with time in parasite load was observed in foetal brain although only $52 \%$ of foetal brains were positive and the distribution of the quantitative parasitic load was more heterogeneous (Fig. 1). In contrast, most of the other organs ( $80 \%$ of liver samples and $96 \%$ of lung samples) were positive and the quantitative parasitic load of these organs was more homogeneous (Fig. 1). It was interesting to note that the lung was 1) the more frequently infected organ, and 2) in one case the first organ infected, 12 days after inoculation (guinea pig G).

\section{DISCUSSION}

$\mathrm{T}$ The guinea pig model for toxoplasmosis has been described in various studies (Giraud et al., 1965; Wright, 1972 ; Haumont et al., 2000; Flori et al., 2002). Adult animals may die from infestation with an inoculum of 1,000 or more tachyzoites with the RH strain (Giraud et al., 1965; Bérard-Badier et al., 1968) while they remain resistant to the avirulent strains (Flori et al., 2002). This model shows several features relevant to the study of congenital toxoplasmosis: the structure of the guinea pig placenta is close to that of humans (i.e., hemomonochorial), suggestive of similar modes of transmission. Hormonal control is cyclic (18 days) and duration of gestation is 65 days, long enough to enable comparative studies using different inoculation times (e.g., G20 and G40, in the present study) and/or comparative chemotherapy studies. In 


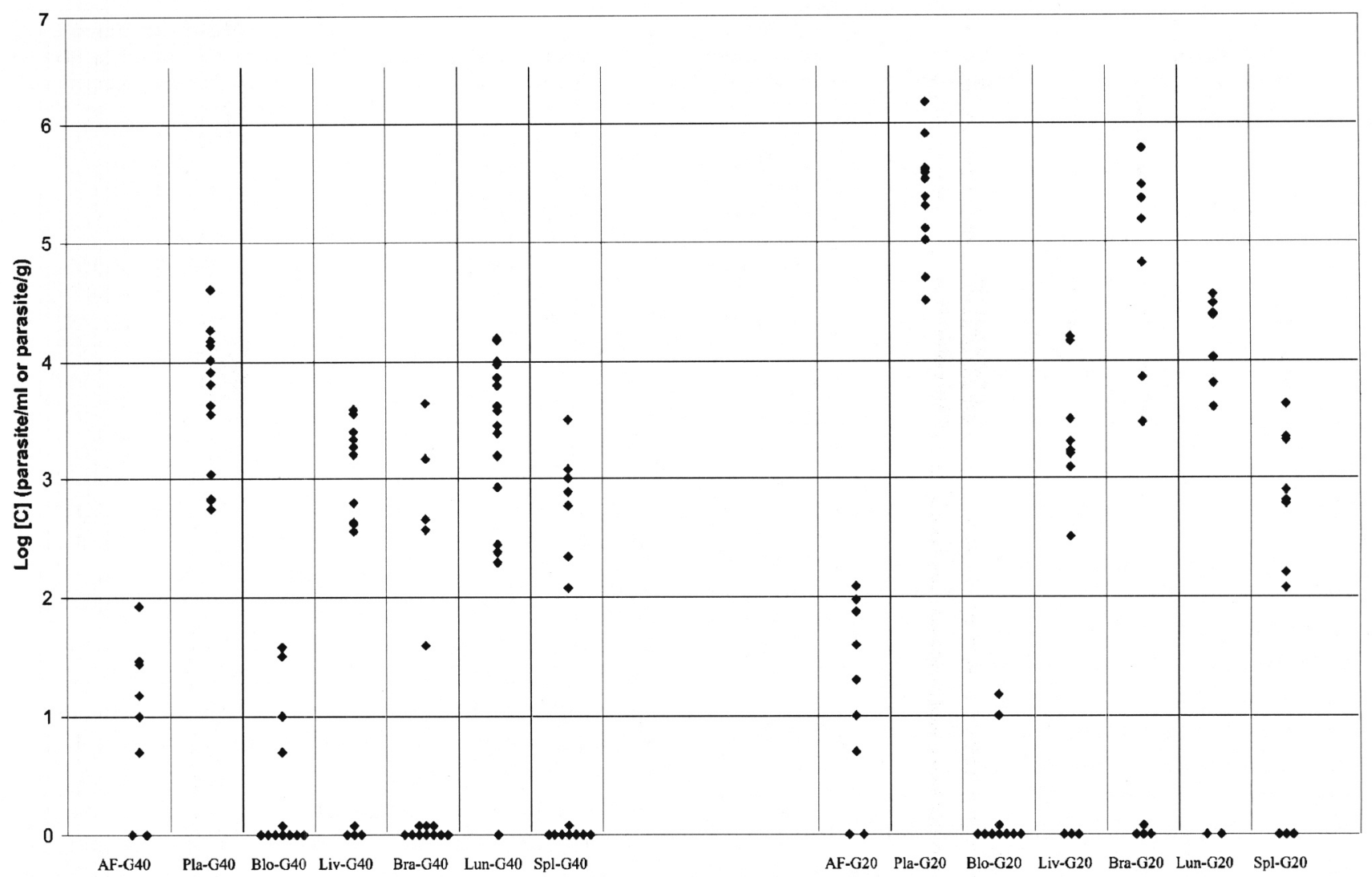

Fig. 1. - Parasite load in different organs, amniotic fluid, and blood samples of fotuses from female guinea pigs infected on G40 after the beginning of gestation (i.e. 20 days before the sampling of tissue on day G60) and on G20 after the beginning of gestation (i.e. 40 days before the sampling of tissue on day G60).

AF: amniotic fluid; Pla: placenta; Blo: blood samples; Liv: liver; Bra: brain; Lun: lung; Spl: spleen. G40: maternal inoculation on day 40 after the beginning of gestation. G20: maternal inoculation on day 20 after the beginning of gestation.

addition, the percentage of maternofoetal transmission increases as a function of the time of inoculation. This tendency which was observed in our previous study using different strains (Flori et al., 2002) is similar to the pathology in humans, although the percentage of transmission in the latter is much lower (Romand et al., 2001). These reasons formed the rationale for the present study and justified the potential extrapolation to human congenital toxoplasmosis.

In addition, in our previous study with this experimental model (Flori et al., 2002), we have demonstrated that strain $76 \mathrm{~K}$ was able to cross the foeto-placental barrier ( $86 \%$ of the cases with proven transmission) and often caused severe congenital infections. These facts led us to use this same strain administered by oral route (route of natural infection) in the present study. The quantification of parasitic load from body fluids or tissues taken from humans or animals is of great interest (Derouin et al., 1995) because it permits to evaluate the degree of affection of the different organs. Qualitative techniques (mouse inoculations, PCR, nested PCR...) and semiquantitative techniques (cell culture technique described by Piketty et al., 1990) have actually been replaced by quantitative techniques such as real time PCR (Costa et al., 2000, 2001; Jaureguy et al., 2001; Flori et al., 2002). This new technique has the following advantages: 1) rapidity and practicability (adaptable for large series), 2) higher sensitivity as compared to cell culture (see below), and 3) precise and reproducible quantification (Flori et al., 2002, present study). We must however note some of its inconveniences: 1) the technique measures the DNA of $T$. gondii and not viable parasites as in the case of mouse inoculation and cell culture, and 2) the cost of the equipment and the test is high.

Regarding the sensitivity of the real-time PCR in this study we were able to detect levels as low as one parasite-DNA extract which corresponds to five parasites $/ \mathrm{ml}$ of body fluid and 20 parasites/g of foetal tissue (Table III). This technique presents a sensitivity similar to classical PCR with body fluids (Pelloux et al., 1998) and superior to the cell culture and PCR technique with tissues (Piketty et al., 1990, our experience, data not shown). Regarding the reproducibility of the real-time PCR in this study, our results show a good reproducibility for the concentrations superior to 10 parasites/extract (Table III), 
concentrations corresponding to the totality of our tissue samples. Only the liquid samples (AF and $\mathrm{CB}$ ) had concentrations close to the 10 parasites/extract threshold. It is important to note that these concentrations are significantly lower than those in the tissues (see Results). We can therefore suppose that the tissue parasite loads measured well represent parasites sequestered in the tissues and not those circulating in blood vessels.

Moreover, we tried to standardize our experimental model as much as possible. To achieve this, it was necessary to sacrifice the guinea pigs a few days before delivery. Thus, animals were sacrificed at the 60th day of gestation, with samples from different tissues taken either 40 days or 20 days after infection. This allowed us 1) to recover and associate the amniotic fluid and the placenta with the foetal organs, 2) to prevent maternal reinfection after delivery due to cannibalism of the placenta and possible infection of the neonates, and 3) to monitor the interval between infection and sampling. The interval between infection and recovery of the samples was found to be an important parameter as shown by our results, i.e. the cerebral and placental parasite loads were much higher in the guinea pigs infected 40 days before sampling than those infected 20 days before sampling. $\odot$ n the other hand, the liver, the lung and the spleen did not show a similar increase according to time interval between infection and sampling (See Results and Fig. 1). We can also note that the cerebral parasite load remained negative 12 days (guinea pig G), 15 days (guinea pig B) and even after 20 days (guinea pig F) after inoculation whereas the majority of other organs were already positive. This shows the much slower appearance of the parasites in the brain.

The main objective of this study was to evaluate the affection of the different foetal organs after maternal infection with $T$. gondii. To our knowledge the degree of affection has not been quantified up to the present time. In this study, from the large number of foetal organs studied, we were able to demonstrate that multiple organs are affected and that the degree of affection of each organ is different.

Quantitative PCR determination of parasite loads may be an important element in the understanding of congenital toxoplasmosis. It is possible to get more accurate information on the parasite burden kinetics in the different tissues for a better understanding of the evolution of the infection in the foetus. These data could be used for designing therapeutic or vaccine development studies in the future.

\section{AKNOWLEDGEMENTS}

Massa for the animal facility and production of the parasites and the staff of the laboratory of parasitology for skillful technical assistance.

\section{REFERENCES}

Azjenberg D., Banuls A.L., Tibayrenc M. \& Darde M.L. Microsatellite analysis of Toxoplasma gondii shows considerable polymorphism structured into two main clonal groups. International Journal of Parasitology, 2002a, 32, 27-38.

Azjenberg D., Cogne N., Paris L., Bessières M.H., Thulliez P., FiliSetTi D., Pelloux H., Marty P. \& Darde M.L. Genotype of 86 Toxoplasma gondii isolates associated with human congenital toxoplasmosis, and correlation with clinical findings. Journal of Infectious Diseases, 2002b, 186, 684-689.

Bérard-Badier M., Laugier M., Louchet E. \& Payan H. Le placenta dans la toxoplasmose congénitale aiguë expérimentale du cobaye. Pathologie et Biologie, 1968, 16, 829-835.

Bessières M.H., Berrebi A., Rolland M., Bloom M.C., Roques C., Cassaing S., Courjault C. \& Seguela J.P. Neonatal screening for congenital toxoplasmosis in a cohort of 165 women infected during pregnancy and influence of in utero treatment on the results of neonatal tests. European Journal of obstetrics Gynecology and Reproductive Biology, 2001, 94, 37-45.

Beverley J.K.A. Congenital transmission of toxoplasmosis through successive generation of mice. Nature, 1959, 183, 1348-1349.

Costa J.M., Pautas C., Ernault P., Foulet F., Cordonnier C. \& Bretagne S. Real-time PCR for diagnosis and follow-up of Toxoplasma reactivation after allogeneic stem cell transplantation using fluorescence resonance energy transfer hybridization probes. Journal of Clinical Microbiology, 2000, 38, 2929-2932.

Costa J.M., Ernault P., Gautier E. \& Bretagne S. Prenatal diagnosis of congenital toxoplasmosis by duplex real-time PCR using fluorescence resonance energy transfer hybridization probes. Prenatal Diagnosis, 2001, 21, 85-88.

Derouin F. \& Garin Y.J.F. Toxoplasma gondii: blood and tissue kinetics during acute and chronic infections in mice. Experimental Parasitology, 1991, 73, 460-468.

Derouin F., Lacroix C., Sumyuen M.H., Romand S. \& Garin Y.J.F. Experimental models of toxoplasmosis: pharmacological applications. Parasite, 1995, 2, 243-256.

Desmonts G. \& Couvreur J. Congenital toxoplasmosis: a prospective study of 378 pregnancies. New England Journal of Medecine, 1974, 290, 1110-1116.

DubeY J.P. \& URBAn J.F. Diagnosis of transplacentally induced toxoplasmosis in pigs. American Journal of Veterinary Research, 1990, 51, 1295-1299.

Dubey J.P. \& SHEN S.K. Rat model of congenital toxoplasmosis. Infection and Immunity, 1991, 59, 3301-3302.

Dubey J.P., Shen S.K., Kwok O.C.H. \& Thullez P. Toxoplasmosis in rats (Rattus norvegicus): congenital transmission to first and second generation offspring and isolation of Toxoplasma gondii from seronegative rats. Parasitology, 1997, 115, 9-14.

Flori P., Hafid J., Bourlet T., Raberin H., Genin C. \& Tran Manh Sung R. Experimental model of congenital toxoplasmosis in guinea pigs: use of quantitative and qualitative PCR for the study of maternofetal transmission. Journal of Medical Microbiology, 2002, 51, 871-878. 
Foulon W., Villena I., Stray-Petersen B. Decoster A., Lappalainen M., Pinon J.M., Jenum P.A., Hedman K. \& Naessens A. Treatment of toxoplasmosis during pregnancy: a multicenter study of impact on fetal transmission and children's sequelae at age 1 year. American Journal of Obstetrics and Gynecology, 1999a, $180,410-415$.

Foulon W., Pinon J.M., Stray-Pedersen B., Pollak A., Lappalainen M., Decoster A., Villena I., Jenum P.A., Hayde M. \& Naessens A. Prenatal diagnosis of congenital toxoplasmosis: a multicenter evaluation of different diagnostic parameters. American Journal of Obstetrics and Gynecology, 1999b, 181, 843-847.

Freyre A., Falcon J., Correa O., El Elhou S., Mendez J. \& Gedda C. Congenital transmission of experimental chronic toxoplasmosis in rats. Journal of Parasitology, 1999, 85, 746-748.

Fricker-Hidalgo H., Pelloux H., Racinet C., Grefenstette I., Bost-Bru C., Gouluer-Fleuret A. \& Ambroise-Thomas P. Detection of Toxoplasma gondii in 94 placentae from infected women by polymerase chain reaction, in vivo, and in vitro cultures. Placenta, 1998, 19, 545-549.

Giraud P., Payan H., Toga M., Berard M., Dubois D. \& Laugier M. Toxoplasmose congénitale aiguë expérimentale du cobaye. Corrélations cliniques, biologiques et anatomiques. Annales d'Anatomie Pathologique, 1965, 10, 337-350.

Godard I., Darcy F., Deslee D., Dessaint J.P. \& Capron A. Isotypic profiles of antibody responses to Toxoplasma gondii infection in rats and mice: kinetic study and characterization of target antigens of immunoglobulin A antibodies. Infection and Immunity, 1990, 58, 2446-2451.

Gratzl R., Hayde M., Kohlhauser C., Hermon M., Burda G., STROBL W. \& POlLaK A. Follow-up of infants with congenital toxoplasmosis detected by polymerase chain reaction analysis of amniotic fluid. European Journal of Clinical Microbiology and Infection Diseases 1998, 17, 853-858.

Hafid J., Tran Manh Sung R. \& Raberin H. Détection des antigènes circulants de Toxoplasma gondii par réaction d'immunoprécipitation dans la toxoplasmose murine. (Detection of circulating antigens of Toxoplasma gondii using immunoprecipitation reactions in murine toxoplasmosis.) Annales de la Société Belge de Médecine Tropicale, 1989, 69, 49-56.

Haumont M., Delaye l., Garcia l., Jurado M., Mazzu P., Daminet V., Verlant V., Bollen A., Biemans R. \& Jacquet A. Protective immunity against congenital toxoplasmosis with recombinant SAG1 protein in the guinea pig model. Infection and Immunity, 2000, 68, 4948-4953.

Hezard N., MarX-Chemla C., Foudrinier F., Villena I., Quereux C., Leroux B., Dupouy D., Talmud M. \& Pinon J.M. Prenatal diagnosis of congenital toxoplasmosis in 261 pregnancies. Prenatal diagnosis, 1997, 17, 1047-1054.

Hohlfeld P., Daffos F., Costa J.M., Thulliez P., Forestier F.\& VIDAUd M. Prenatal diagnosis of congenital toxoplasmosis with a PCR test on amniotic fluid. New England Journal of Medecine, 1993, 331, 695-699.

Jauregui L.H., Higgins J., Zarlenga D., Dubey J.P. \& Lunney J.K. Development of a real-time PCR assay for detection of Toxoplasma gondii in pig and mouse tissues. Journal of Clinical Microbiololy, 2001, 39, 2065-2071.

Kupferschmidt O., Kruger D., Held T.K., Ellerbrok H., Siegert W. \& JANTSCHKE K. Quantitative detection of Toxoplasma gondii DNA in human body fluids by TaqMan polymerase chain reaction. Clinical Microbiology and Infection, 2001, 7, 120-124.

Lin M.H., Chen T.C., Kuo T.T., Tseng C.C. \& Tseng C.P. Realtime PCR for quantitative detection of Toxoplasma gondii. Journal of Clinical Microbiology, 2000, 38, 4121-4125.
Luo W., Aosai F., Ueda M., Yamashita K., Shimizu K., Sekiya S. \& YANO A. Kinetics in parasite abundance in susceptible and resistant mice infected with an avirulent strain of Toxoplasma gondii by using quantitative competitive PCR. Journal of Parasitology, 1997, 83, 1070-1074.

Paulino J.P. \& Victor R.W.A. Experimental congenital toxoplasmosis in Wistar and Holtzman rats. Parasite, 1999, 6, 6366.

Pelloux H., Guy E., Angelici M.C. et al. A second European collaborative study on PCR for Toxoplasma gondii, involving 15 teams. FEMS Microbiology Letters, 1998, 165, 231-237.

Piketty C., Derouin F., Rouveix B. \& Pocidalo J.J. In vivo assessment of antimicrobial agents against Toxoplasma gondii by quantification of parasites in the blood, lungs, and brain of infected mice. Antimicrobial Agents of Chemotherapy, 1990, 34, 1467-1472.

Pratlong F., Boulot P., Issert E., Msika M., Dupont F., BacheLaRd B., Sarda P., Vlala J.L. \& JaRry D. Fetal diagnosis of toxoplasmosis in 190 women infected during pregnancy. Prenatal Diagnosis, 1994, 14, 191-198.

Remington J.S., Jacobs L. \& Melton L. Congenital transmission of toxoplasmosis from mother animals with acute and chronic infection. Journal of Infection Diseases, 1961, 108, 163-173.

Robert-Gangneux F., Gavinet M.F., Ancelle T., Raymond J., Tourte-Schaefer C. \& Dupouy-Camet J. Value of prenatal diagnosis and early postnatal diagnosis of congenital toxoplasmosis: retrospective study of 110 cases. Journal of Clinical Microbiology, 1999, 37, 2893-2898.

Roberts C .W. \& AleXander J. Studies on a murine model of congenital toxoplasmosis: vertical disease transmission only occurs in BALB/c mice infected for the first time during pregnancy. Parasitology, 1992, 104, 19-23.

Romand S., Wallon M., Franck J., Thulliez P., Peyron F. \& Dumon $\mathrm{H}$. Prenatal diagnosis using polymerase chain reaction on amniotic fluid for congenital toxoplasmosis. Obstetrics and Gynecology, 2001, 97, 296-300.

Schoondermark-Van de Ven E.M., Melchers W.J., Galama J.M., Camps W., Eskes T.K. \& Meuwissen J.H. Congenital toxoplasmosis: an experimental study in rhesus monkeys for transmission and prenatal diagnosis. Experimental Parasitology, 1993, 77, 200-211.

Schoondermark-Van de Ven E.M., Melchers W.J., Galama J.M., Meuwissen J.H. \& Eskes T.K. Prenatal diagnosis and treatment of congenital Toxoplasma gondii infections: an experimental study in rhesus monkeys. European Journal of Obstetrics Gynecology and Reproduction Biology. 1997, 74, 183-188.

Thapar M.K., Kumari G.L., Shrivastav T.G. \& Pandey P.K. Hormonal control of implantation in guinea pigs. Steroids, 1988, 52, 85-108.

WRIGHT I. Transmission of Toxoplasma gondii across the guineapig placenta. Laboratory Animals, 1972, 6, 169-180.

Zenner L., Darcy F., Cesbron-Deslauw M.F. \& Capron A. Rat model of congenital toxoplasmosis: rate of transmission of three Toxoplasma gondii strains to fetuses and protective effect of a chronic infection. Infection and Immunity, 1993, 61, 360-363.

Zenner L., Darcy F., Capron A. \& Cesbron-Delauw M.F. Toxoplasma gondit: kinetics of the dissemination in the host tissues during the acute phase of infection of mice and rats. Experimental Parasitology, 1998, 90, 86-94.

Reçu le 9 juillet 2002 Accepté le 7 mars 2003 